\title{
Advancing justice in the search for peace: An exegetical study of Micah 6:8 as a recipe for peace in Africa
}

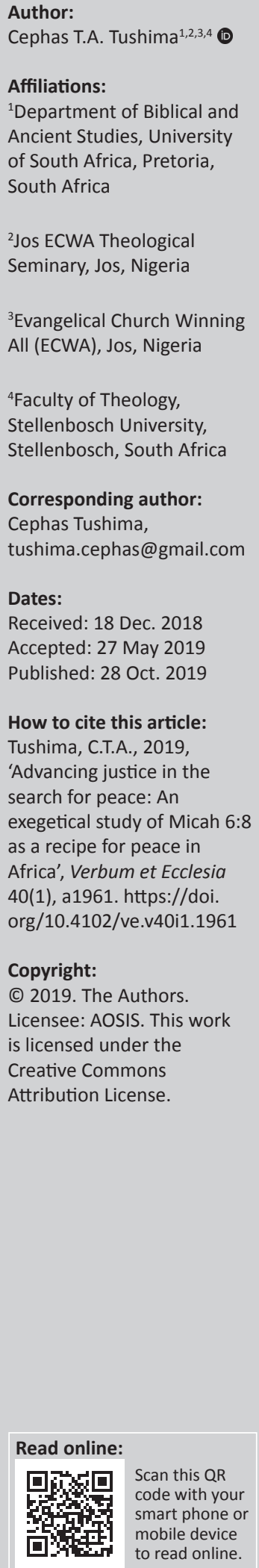

Peace has been elusive to the greater part of the African continent. For peace to thrive in any place, certain fundamentals for societal cohesion must be entrenched in its social fabric. This essay studies Micah 6:8, with the aim of identifying such important biblical fundamental principles for societal peace. This article employs rhetorical analysis with the historical grammatical method of textual analysis to exegete Micah 6:8. The article begins with an exploration of the biblical concepts of peace and justice. It then exegetes Micah 6:8 in its historical and literary contexts, explaining the three critical demands of $\mathrm{YHWH}$ in the verse, namely, to act justly (both in the judicial administration of justice and in the maintenance of right relationships in the community), to love mercy (highlighting loyal loving commitment to God and the brotherhood in covenant) and to walk humbly with God (a basic call to discipleship). This is followed by an analysis of the African crisis situation, pointing out the similarities between the socio-economic conditions of Micah's times and ours. Ultimately, these biblical principles are interconnected with the African situation, showing how the implementation of Micah's justice agenda (employing the retributive, restorative and redistributive elements of justice) is a recipe for peace in Africa.

Intradisciplinary and/or interdisciplinary implications: This essay challenges the approaches towards the pursuit of peace in Africa and calls for a biblical justice approach for finding peace. It works across the disciplinary fields of biblical studies, biblical theology, public theology and social justice.

Keywords: peace; justice; Micah; Hesed; warlords; civil war; peace mediation; African crises.

\section{Introduction}

Peter Tosh sang in the 1970s, 'Everyone is crying out for peace, yes/none is crying out for justice ... I don't want no peace/I need equal rights and justice'. Peter Tosh (or perhaps, the authors of the song, Rolando E. Mclean, Anthony Dehaney and A. Brown) raised a fundamental question with regard to the pre-conditions for peace. Peace does not exist in a vacuum: some fundamentals must be on ground to ensure that peace ensues. The long absence of peace in large sections of Africa is indicative of the absence of these fundamentals. From Peter Tosh's song, two of these fundamentals are highlighted as prerequisites for peace, namely, equal rights and justice. In this essay, I will be exploring the same question that Tosh broached, but from a faith perspective. I will be carrying out an exegetical study of Micah 6:8, with the view of gleaning for anchors on which efforts for sustainable peace in Africa will be tethered. In this process, I will be employing literary analysis of contemporary literature and historical grammatical exegesis of the biblical text. It will be pertinent at this point to seek an understanding of the two key terms, 'peace' and 'justice', before proceeding further with the conversation.

\section{The Biblical concepts of peace and justice}

In explaining peace, Ekanola (2009) stated:

Peace is one of the concepts most frequently used in sociopolitical discourse, but not enough efforts have been made to clarify it and arrive at an adequate and concise definition that would be generally acceptable. (pp. 222-223)

Further expatiating on this theme, he posits that for individuals, peace means inner emotional calm or tranquillity, while for societies it refers to the absence of violence. Dissatisfied with a purely negative definition of peace, based on what is absent, Ekanola sets out to identify the positive elements that should constitute a peaceful environment. His list includes physical security, emotional well-being of members of the society, harmonious relationships among fellow citizens and an efficient system of governance (Ekanola 2009:223). 
Although Ekanola made efforts to expatiate the concept of peace beyond the mere absence of conflict, he did not go far enough. It is pertinent then to turn to the biblical conceptions of peace for an all-encompassing understanding of peace. On this note, Longman (2013) stated:

The Bible presents peace as the state of completion of God's plan, fulfillment of his promise for his people on earth ... In fact, attaining peace on an individual level is tied more closely to one's relationship with God than to one's inner psychological state. (p. 1284)

The above definition of peace recalls the rupture of the relationship between humanity and God not long after creation (Gn 3). Subsequently, temporary peace between the Creator and his creatures was sought in the Old Testament (OT) through the sacrifice of peace offerings, which were later understood as pointers to the ultimate sacrifice of the Messiah, who will be both the priest and the sacrifice for the restoration of an enduring peace between God and his people. The birth narratives of Jesus Christ are replete with peace motifs, beginning with the prophecy of Zechariah (Lk 1:79) to the annunciation of the angels ( $L k 2: 14$ ) and to the thanksgiving of Simeon (Lk 2:29). Building on this, apostolic teaching highlights the divine initiative for the restoration of the broken relationship (cf. Rm 5:1, 8-11; 2 Cor 5:18-21; Col 1:20-22; Eph 2:14-17; Jn 14:27; 16:33; see Longman 2013:1284-1285).

Longman's explanation of peace deals almost exclusively with pietistic introspection without the social implications of the inner harmony with one's Creator for society at large. As if to address this shortcoming, drawing on the rich background of the words for peace in the OT (šâlôm and its verb form šālēm) and New Testament (NT) (eirēneuō), Leland Ryken, James Wilhoit and Tremper Longman show that the former refers to the state of 'being uninjured, safe, and sound, or whole', while the latter 'refers mainly to being in political peace', and further affirm that, in the Bible, 'genuine peace is always just and moral' (Ryken, Wilhoit \& Longman 1998:632).

Youngblood gives a very elaborate explanation of the biblical terms for peace both in the OT and the NT. Highlighting the richness of the Hebrew word šălôm, he notes that its semantic domain includes 'fulfillment, completion, maturity, soundness, wholeness (both individual and communal), community, harmony, tranquillity, security, well-being, welfare, friendship, agreement, success, and prosperity' (Youngblood 1986:731-733). With regard to the NT, Youngblood identifies eirene and its derivatives as the cognate for šălôm, and that they express the basic meaning of 'peace, well-being, rest, reconciliation with God, and salvation in the fullest sense' (Youngblood 1986:732). Therefore, in the biblical sense (both in the OT and the NT), the two words that have been translated to the English world 'peace' have connotations beyond the mere absence of conflict. They stand for the all-rounded well-being of individuals and the community in which they live. Peace, in the biblical sense, therefore, implies living well (spiritually, psychologically, socially, materially, financially and politically) and being well secured in one's self and environment. Before turning to Micah 6:8 to see how such a society could be achieved, let us presently explore what justice, in the Bible, means.

Justice, in our English translations of the Bible, is often a translation of the Hebrew word mišpat. Typically, the way it is used in the Hebrew Bible, mišpat often has to do with the process, place, actants, rules and procedures concerned with the administration of justice. For a full explanation, see BDB, 1048-49. Not uncommonly, mišpat occurs with its complimentary word pair şadāqāh, a term usually translated into English as 'righteousness', but every so often is also rendered as 'justice'. Discussing this word pair, Tushima (2011) writes:

This word pair even more richly embodies the thematic of justice, when used as a hendiadys or combined in a parallelism (Gen 18:19; Deut 32:4; 33:21; 2 Sam 8:15; 1 Kgs 10:9; Job 37:23; Ps 72:2; 103:6; Prov 21:3; Isa 56:1; 58:2-7). Justice (and righteousness) is imbued with the qualities of integrity in purpose, rectitude in conduct, and equity in social dealings; it is a negation of oppression, decadence, and inequity. It closely approximates our modern concept of social justice. (p. 20)

Tushima (2011) further illustrates, with Deuteronomy 10:1618 , that the biblical concept of justice has its roots in the person, character, redemptive acts of $\mathrm{YHWH}$ and his covenant with his people of Israel. The covenant relationship, then, becomes the vantage point from which the Torah insists, in its ethical demands, on true filial relationships among the Israelites (cf. Dt $1: 16 ; 4: 13-14,31 ; 5: 1-4 ; 9: 9-11 ; 15: 1-11)$. Understood in this way, the Torah ceases to be a rigid legal code, but rather a fundamental norm, among YHWH's covenant people, of covenantal relationships of loyalty and fidelity, firstly, to God and, then, to one another.

This word pair (or hendiadys) often signifies the intrinsic obligation for compliance to customary norms (either in the realms of religion or in civil affairs). Implicit in it is the duality of the claim and the incumbent duty for the beneficiary and the one required to disburse the duty, respectively. It is in this regard, for instance, that Judah, while refraining from his demand for capital punishment for his daughter-inlaw, with whom he unwittingly had an amorous incestuous relationship (Tamar), states that she was more justified than himself. This is because she had the claim on Jacob of a kinsman-redeemer husband, and Jacob had the incumbent duty of providing her with such, which he had recoiled from executing. Understood in this way, biblical justice is akin to our contemporary concepts of social justice and its concomitant concepts of fundamental human rights, which if fully implemented in a society should make way for good governance, peace and harmony, social progress, economic development, prosperity, and the health and well-being of the citizenry.

\section{An exegetical analysis of Micah 6:8}

It is important to situate this passage in its context, both the historical and literary contexts, to understand it properly. 
Historically, Micah prophesied in the 8th century BC, like his other contemporaries, Amos, Hosea and Isaiah. This was a period of Israelite renaissance, for the kingdoms of Israel and Judah experienced peace, prosperity and territorial expansions that they had not seen in many years. During the reigns of Jeroboam II of the northern kingdom of Israel (786-746) and Uzziah of Judah (783-742), both kingdoms, which were even cooperating with each other rather than competing against each other as they had always done, had reached what would approximate a golden age. Indeed, the dawn of the 8th century ushered in a new lease of life for the northern kingdom. In 802 BC, the Assyrians under Adad-Nirari III crushed Damascus, thereby ending Syria's subjugation of Israel. About the same time, Egypt was also weakened by internal strife, and it could not venture into Palestine. Jeroboam II, therefore, was able to recover much of the territory that Syria had previously seized from Israel (cf. 2 Ki 14:28) (McComiskey 1985a [Am]:269). On this period, Thomas Edward McComiskey (1985a [Am]) wrote:

\begin{abstract}
It was a time of great economic prosperity, fostered, for a time, by the absence of international crises and by the mutual cooperation of both kingdoms. Excavations at the site of the ancient city of Samaria have yielded ivory inlays that attest to the accuracy of Amos' description of the luxurious life enjoyed by the prosperous citizens of this city (Am 6:4). (p. 395)
\end{abstract}

Seasons of socio-economic prosperity always prove to be testing times for God's people. The ancient kingdoms of Israel and Judah were no exceptions. As Tushima (2016) observed, upward mobility in socio-economic status predictably is concomitant with:

$[A]$ lust for more. Consequently, there emerges an inert selfcenteredness that results in exploitation of the weakest elements of the society for the further advance of those already privileged. The greed of the emergent urban elites of ancient Israel ruptured the Israelite society of shared economic burdens through the kinsman redeemer system. (p. 40)

Situations such as this ineluctably result in monumental social injustices of all shades in all spheres of life. It is to this kind of society, which is not unlike ours today, that Micah was called to minister, hence the abiding relevance of his message to our own times as well.

At the literary level, Micah's book can be divided into three sections consisting of three oracles, namely:

$[T]$ he first oracle - Israel's impending judgment and her future restoration (Mi 1:1-2:13); second oracle - the prophet's indictment of the leaders of the house of Israel and Israel's future hope (3:1-5:15); and third oracle - God's lawsuit with Israel and the ultimate triumph of the kingdom of God (6:1-7:20). (McComiskey 1985b [Mi]:401)

Our text falls within the third oracle consisting of God's covenant lawsuit against Israel. Micah 6:8 is part of the clear enunciation of the lawsuit in Micah 6:1-8.

The covenant lawsuit in Micah 6:1-8, in dramatic fashion, begins with summons to $\mathrm{YHWH}$ to arise and plead his case against Israel in the presence of his assembled witnesses (v. 1). YHWH, then, calls upon the mountains and foundations of the earth to serve as his witness (v. 2). This conforms to the covenant structure of YHWH's relationship with Israel. To conclude the Deuteronomic covenant, YHWH had summoned the heavens and the earth to be his witness (Dt 30:19; 32:1, 28; cf. 4:26). Now that the covenant had been violated, the same natural phenomena would be YHWH's witnesses in his lawsuit against his people. As in the covenant structure, where the suzerain lays out a historical prologue that catalogues his goodness to the vassal, YHWH in this disputation against his people recalls his covenant of faithfulness to them, recalling his saving acts on their behalf (vv. 3-5). Again in dramatic fashion, Micah presents vv. 6-7 as if it were Israel's response to God, as if having realised their failure they wished to remedy it and so were inquiring to know what they ought to do. McComiskey notes that there is irony in Israel's response, as the response of Israel and YHWH's reply in v. 8 contrasts 'external religion (to which they clung) with true religion' (McComiskey 1985 [Mi]:435), which they lacked. The problem of false religion that focussed on the external formal ritualistic practices was regularly denounced by Israel's prophets (cf. 1 Sm 15:22; Is 1:11-15; 66:1-3; Jr 7:21-22; Am 5:21-22; Hs 6:6). It is to the inner religion of the heart and covenant loyalty that our text, Micah 6:8, summons Israel.

\section{A discussion of MICAH 6:8}

הגיד לך אדם מה־טוב ומה־יהוה דורש ממך כי אם־עשות משפט ואהבת חסד והצנע לכת עם־אלהיך:

My translation of the text:

${ }^{1} \mathrm{He}$ has declared ${ }^{2}$ to you, O man, what is good. And what does YHWH seek from you, but to do justice and cherish ${ }^{3}$ covenant loyal love, ${ }^{4}$ and walk humbly ${ }^{5}$ with your God?

Exegetical notes on the translation:

${ }^{1}$ The LXX begins the verse with an interrogative marker ' $\varepsilon i$ ', signifying that the entire verse is a rhetorical question. This textual variant (of an ancient translation) is not significant.

${ }^{2}$ While there are a number of other words that could have been used, the choice of נג is deliberate, with its inherent meaning of both public pronouncement and the disclosure of that which has been hidden previously (Dt 5:5; $1 \mathrm{Sm}$ 15:16; 2 Sm 7:11; 2 Ki 4:27; Is 48:6; Ps 19:12; 145:4). By this, the prophetic declaration of the divine purpose, indicative of the extant divine revelation, is denoted.

${ }^{3}$ The word אהב literally means love, but when used for nonhuman things may also connote the idea of to cherish or hold as dear, which is even true of human love as well (cf. Gn 27:9, 14; Pr 21:17; 2 Chr 26:10; Hs 10:11).

${ }^{4}$ The phrase 'covenant loyal love' is my rendition of the Hebrew word herein below. 
${ }^{5}$ The two Hebrew words translated here as 'walk humbly' (הצנע are infinitives. The first is an infinitive construct (which more regularly functions in the place of a finite verb), while the second is an infinitive absolute (which is more commonly used in the place of an adverb).

As if in reply to Israel's orchestrated inquiry (vv. 6-7) into what they were supposed to do in response to their indictment by $\mathrm{YHWH}$, the prophet begins in verse 8 , 'He has declared to you, O Man, what is good'. The objective phrase 'what is good' simply refers to that which they ought to have done (which they are now asking about). The verb I translated as 'declared' (הגיד) is in the causative stem (hiphil), third person masculine singular with a perfect aspect. The perfect aspect is indicative of completed action in the past, while the hiphil stem shows that YHWH had caused the action inherent in the verb to be executed. In this case, it has the idea that $\mathrm{YHWH}$ had already initiated the declaration of his expectation to the people of Israel. This is a less than veiled reference to prior proclamations of the divine will to YHWH's covenant people both in the Torah and through the ministry of the prophets that preceded Micah. Inherent in the meaning of the word is both the idea of the disclosure of that which is hidden and public proclamation. By implication, even if the divine will were hidden, $\mathrm{YHWH}$ had already caused it to be proclaimed publicly. Thus, Israel could not plead ignorance.

The last part of the verse is set in the format of an interrogative. However, this is a rhetorical question - a statement of propositional truth in question form. This part of the verse consists of the question proper and the response, and the response to the question has three components. In the question proper, the prophet asks, 'What does YHWH seek from you?' The verb I have translated as 'seek' (דiֹ) is a masculine singular participle in the indicative (qal) stem with an active voice. The participial form of the verb indicates its durative (non-complete) sense, that is, the action of the verb is ongoing. The semantic range of the word includes 'to inquire into or investigate', 'to care about', 'to resort to or frequent', 'to consult as in prayer or to worship', 'to ask for, demand, or require' (BDB, 205). Of all these possible meanings, the last is the most appropriate here, that is, the sense of what God requires or demands of his covenant people. Examples of the use of this verb with this sense in other passages in the Bible include: Genesis 9:5; Deuteronomy 18:19; 23:21; 2 Chronicles 24:6, 22; and Ezekiel 20:40; 33:6. Used as a participle, therefore, it means that this is an unending demand that God makes of his people; it is not a once and for all thing. Commenting on the nature of this question, Brueggemann (2010) stated:

The question implies and assumes a certain positioning between YHWH and Israel or between YHWH and humanity. YHWH asks and Israel must respond. YHWH 'requires' and humanity must answer. The God of generous rescue (v. 4) is the God who must be obeyed. (pp. 14-19)

That which YHWH requires is restated, for the avoidance of doubts.
The response to the rhetorical question is prefaced with the deictic particle כי־אם. These particles usually stand by themselves for different uses, but when combined to form a single particle that serves to conjoin clauses, the clause(s) that follow it indicates the logical conclusion of the sentence (Holladay 1996 [HALOT, 156]). In our verse, it conjoins the question to its logical expectation, namely, 'What does the Lord demand of you, except to ...' In other words, the deictic particle כי־ introduces the ensuing exceptive clauses, all three of which have no finite verbs but use three infinitive constructs, in the place of finite verbs. Tushima explains that typically infinitive absolutes are more versatile than infinitive constructs, and that the former are used much more frequently in the place of finite verbs than the latter. However, the use of infinitive absolutes as finite verbs is mostly in narrative discourses, whereas infinitive constructs are usually used in the place of finite verbs in poetic discourses. Our text, in this case, is a poetic discourse. Thus, the infinitive constructs here have to be understood as serving as finite verbs (2011:186-87; cf. Waltke \& O'Connor 1990:59-610). The ensuing response to the question has three aspects: the first is concerned with horizontal human relations within the covenant community, the second is a combination of both vertical relationship to YHWH and horizontal relations with other people and the last focusses on relations with YHWH.

The first aspect of the response to the questions states, 'to do justice'. As explained above, the biblical concept of justice has two components to it, namely, the judicial administration of justice, on the one hand, and the maintenance of right relationship with other fellow covenant community members on the other hand. Both of these were critical in the time of Micah. Those charged with administering justice were expected to be just and fair to all (cf. Ex 23:2-8; Lv 19:15; Dt 1:16-17; 16:19). Yet, Micah accused the judges and the leadership of Israel of perversion of justice (Mi 3:1-3, 5, 9-10; $7: 3-4)$. In this regard, the prophet, the seer, the prince and the judges were all implicated in the perversion of justice for the sake of sordid gain, and Micah had pronounced God's impending judgement against them. Relationships among the covenant people were also fractured (cf. Mi 2:1-2, 8-9; $6: 10-12,16 ; 7: 2)$. The brokenness in interpersonal relationships was manifested in the violent seizures of the property of the weak and powerless members of the Israelite society (Mi 2:2, 8-9a; 6:16; cf. $1 \mathrm{Ki} 21$ ), possible rape of children (Mi 2:9b), corrupt and deceitful business practices (Mi 6:10-12) and violent murders of the innocent (Mi 7:2). It was in the midst of all this that $\mathrm{YHWH}$ through his prophet reminded Israel of his demand of them - to act justly, that is, to restore broken relationships. On the implication of this demand, Brueggemann (2010:14) observes that to do justice 'is to be sure that the neighbour is well provided for'. This certainly was in contrast to what was happening at the time, where the neighbour was being ripped off rather than being cared for.

The second requirement is to 'cherish covenant loyal love'. The noun I translate here as 'covenant loyal love' is hesed, a word so rich in meaning that no single English word 
could convey its meaning. Nelson Glueck was the first, in modern times, to give serious effort to the study of this word. Presupposing an existent (covenant - berit) relationship, Glueck defines the term as relating to 'conduct in accord with a mutual relationship of rights and duties, corresponding to a mutually obligatory relationship ... principally: reciprocity, mutual assistance, sincerity, friendliness, brotherliness, duty, loyalty and love' (Glueck 1967:55).

Hesed, both in the Bible and in contemporary biblical literature, is often associated with other Hebrew concepts such as 'emet and 'èmûnāh (i.e. truth and faithfulness), rahàmîm (mercy, kindness), among others, which ultimately affect how it is understood. Tushima (2013), in this vein, wrote:

$[W]$ e can conclude that, Hesed is closely connected with such terms as hānan (grace: Gen 19:19; 39:21), 'emet (truth: Gen 24:27, 49), 'émûnāh (faithfulness; Ps 100:5; ), șadāqāh (righteousness; Ps 33:5; 85:10-12; Hos 10:12), rahămîm (mercy: Exod 34:6; Neh 9:17), 'ahăba (love: Deut 7:7-9; Jer 31:3), and berît (covenant: Deut 7:9; 1 Sam 20:8). Thus, it is almost impossible to define hesed by itself. It has to be understood within its web of interconnectedness with all these other terms. (pp. 92-93)

Within the web of interconnectedness, the meaning that emerges for the word is the sense of a person's free-willing generous disposition for seeking the good of another that transcends common goodness and is expressed beyond ordinary expectation. It is first of all an act of God to his covenant people, based on his sovereign elective grace, not on merit. Such amazing love shown to the people of God is expected to elicit a corresponding loyal loving disposition in God's people towards him (first and foremost) and secondarily towards other members of the covenant community. On this derivative sense of hesed (at the horizontal level of relations with other members of the covenant community), Brueggemann (2010:14) states that it means 'to practice a life of reliable solidarity'. Brueggemann rightly points out that the key terms at the heart of these first two demands (mišpat and hesed) echo the two commandments at the heart of Yahwistic religion: love of God and love of the neighbour (Brueggemann 2010:15).

The third demand that YHWH made of Israel in this verse is to 'walk humbly' with him. Commenting on this third demand, Keil observes that the humble walk with God means to walk 'in fellowship with God, as Israel, being a holy priestly nation, ought to walk', and in addition to the first demands he writes, '[w]ithout these moral virtues, sacrificial worship was a spiritless opus operatum, in which

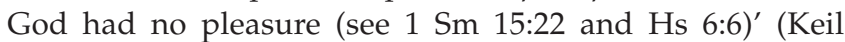
2001:336). There are three key phrases in this verse: the first two are infinitival phrases, while the last is a prepositional phrase. The first term, הצנע, which is prefixed with a conjunctive waw, is an infinitive absolute of the hiphil stem from the root צנע (in the qal stem meaning, 'to be modest' or 'to be humble', and in the hiphil stem meaning 'to show to be humble'; $B D B, 857)$. The term is serving an adverbial purpose because the following infinitives construct serves as the finite verb, as explained above. By this, הצנע serves to indicate the manner of the walk, that is, it answers the question of how the walk is to be done-humbly.

The second phrase of YHWH's third demand is לכת, an infinitive construct in the qal stem from the root, הלכת , which literally means 'to walk', 'to proceed', 'to move', 'to go', 'to depart', 'to go away' or 'to arrive', with reference to physical movement $(B D B, 229)$. It is also used figuratively with different nuances, but the following examples will suffice for our purpose: an invitation for God to come into a situation (Ps 80:3); God's invitation of the thirsty to come to him (Is 55:1) and with reference to life's journey (cf. Dt 8:16; Jos 1:7, 9; 2 Sm $7: 9 ; 8: 6,14 ;$ Ps $1: 1 ; 23: 4 ;$ Is $30: 21 ;$ Jr $6: 16)$. The third example of life's journey is the one that connects with our text, the walk of life - the way life is to be lived; it is to be lived in humility.

In traditional societies, walking, especially long-distance walks, just like the journey of life, is not something that one undertakes alone. This truth is well captured in the East African proverb, 'If you want to go fast, go alone, but if you want to go far, go in company'. Because life's journey is such a long journey, the best company is indicated in the text with the prepositional phrase, 'with your God'. God is the one who knows the way, who will be the guide, indicating the way in which one is to walk (Is 30:21); who will be the protector (Ps 23:4); who knows the good way that offers rest (Jr 6:16) such a way is the way of the Torah (Dt 8:6). It is in this understanding that the Jewish rabbis developed Halaka as a direction for life. In the NT, it is the way of discipleship. It is in this light that Peter exhorted his readers to humble themselves under the mighty hand of God (Pt 15:6). Paul encouraged his readers not to walk as the unbeliever did (Eph 4:17) nor as some pretending believers did as enemies of the cross (Phlp 3:18-19), but to walk in love as children of light (Eph 5:2, 8), in a manner worthy of the God who called them (Eph 4:1), following the example of Paul and other faithful saints (Phlp 3:17), and to walk in good works (Eph 2:10). The person who walks this way with God will certainly do justice and show loyal love both to God and his fellow humans as well.

\section{The African context and the relevance of Micah's message}

Let me begin this section with a qualification, namely, that I am acutely aware of the spatial largeness and miscellany of the African continent, and even much more so aware of its social, political, cultural and economic diversity. Thus, my presentation here is prone to the pitfalls of all generalisations. Nevertheless, if generalisation is to be avoided wholesale, then no academic research would be possible because it is the norm to work with historical particularity with the goal of ultimate generalisation, all things being equal. I am obligated to acknowledge that there are a number of bright spots blazing the trail of the future for Africa; notable examples include Ghana, post-communist Ethiopia and the post-genocide Rwanda. That notwithstanding, the prevailing situation in many other parts of Africa is regrettable, and it is to these that we are referring here. 
Describing the desperate situation of African countries, Ekanola notes that a very precarious state of affairs pervades in virtually all of them. Ekanola (2009) wrote:

They are largely politically unstable and experiencing various levels of economic deterioration, all with dire consequences on the well-being of people. These range from poverty, epidemics, illiteracy, and diverse manifestations of violence. Indeed, the spate of violence in Africa is on the increase, both in frequency and intensity. (p. 222)

Full-blown wars have (and are still) been fought in many African nations such as Democratic Republic of Congo (DRC), Nigeria, Liberia, Sierra Leone, Ivory Coast, Chad, Angola, Central African Republic (CAR), Algeria, Rwanda, Uganda, Ethiopia-Eritrea, Libya, Egypt, Mali, Sudan, South Sudan, Somalia and Burundi. The turning of the Middle Belt of Nigeria into a killing field by the Fulani in collaboration with the Federal Government of Nigeria is well documented (cf. Tushima 2016:46-48).

People have become so inured to violence in Africa that they can even go to the extent of justifying it as a means of bringing development. Writing on this, Ekanola (2009) observes that people who espouse violence to achieve development contend that the human being by nature:

$[I]$ s always seeking for ways to develop himself and is naturally predisposed to violence, with violence being the only means of achieving development, either at the individual or social level. Thus, social peace is conceived of as secondary to social development and is desired only to the extent that it facilitates development in society. If peace stands in the way of progress, people would generally prefer to have war and progress instead of peace and decadence. (p. 222)

Mulongo et al. (2010:549-550) posit that the changing economic systems, especially the movement from socialism to capitalism, have resulted in profit-driven entrepreneurial efforts for wealth creation that has resulted in an unsustainable competition for and exploitation of natural resources. Generally, moments of discontinuous change in the economic fortunes of society results in disequilibrium in the socio-economic order. The natural human instinct for survival activates the baser traits of our humanity, bringing about aggression and violent clashes in the ensuing competition for scarce resources. Writing on a similar note, Tushima (2016:45-46) observes that both the adverse economic hardships of the International Monetary Fund-inspired Structural Adjustment Programme (SAP) in the 1980s and the relative boost in income levels in the post-1999 era after the return to democratic rule resulted in increased communal conflicts owing to competition for land resources either for survival (with regard to the hardships of the 1980s) or the drive for more money and property (in the relative abundance of the new millennium).

Poor attitudes and unsustainable methods of exploitation of natural resources (such as tree cutting and wood burning for charcoal and firewood for fuel; deforestation resulting in depletion of watersheds and wetlands; wildlife poaching; emission of toxic carbon gases into the atmosphere from automobiles, power-generators, industries; and gasflaring in oil-producing areas) have resulted in the further degradation of the natural environment. The consequences have been the fast advances of desertification, catastrophic floods, droughts, dwindling water supply, poor harvests resulting in famine, malnutrition and the spread of disease. All these have stiffened competition for resources, resulting in more conflicts, violence and hence the absence of true peace in much of Africa. The extreme cases of these conflicts include the Rwandan genocide; the wars in CAR, the DRC and diamond-motivated wars in Sierra Leone and Liberia; and the herdsmen attacks on farmers in Nigeria.

These violent situations in Africa tend to inspire spiralling circles of violence, as each offended group seeks its pound of flesh (albeit in its conception of justice-seeking) by perpetrating violence to its perceived enemies. There are three major well-known aspects of justice: retributive, restorative and redistributivejustice. These threeaspects of justiceareallimplied in the Micah text, as its exegesis above shows. In the face of the gruesome acts of violence in our continent, the overwhelming response of the international community has been that of indicting and prosecuting the key figures in these acts of violence. Examples of this include the prosecution of former presidents, Charles Taylor of Liberia and Laurent Gbagbo of Corte D'Ivoire. Thomson (2009:319-338), in addressing the international community's response to group injustices that often results in mass murders, carefully examined the stances of the advocates of retributive and restorative justice, weighing the options of focussing on developing a new morality devoid of colonialism, oppression and greed, on the one hand, and the necessity of just punitive recompense for crimes against humanity on the other hand. To properly address both concerns, she calls for a good understanding of what justice is, and she offers the following explanation (Thomson 2009):

Justice is therefore a matter of relationship - of a better morality and involves all the emotions associated with being wronged, including the desire for vengeance in the name of justice. The argument of how justice is best satisfied has to include a critical appraisal of the practice of justice-making as it seeks to right wrongs, establish better moralities and manage the emotions to promote peace rather than violence. (p. 320)

Her conclusion is that, coming from a Judeo-Christian tradition, she would rather not have justice hijacked to serve violence, but that it is placed in service to peace and reconciliation. Specifically, she writes, 'Where Christian thinking and practice is held captive to a punitive spirit, which calls for punishment as the sole satisfaction of justice, a critique is in order', and she hopes to (Thomson 2009):

[S] hed some light on the relation between punitive and restorative justice, and how we may discern a deeper, more generous and richly textured understanding of justice through a careful listening to the claims of each view. (p. 320)

There is palpable tension between Thomson's stance and the stance implied in the Reggae song of Peter Tosh that we began our discussion with. While dialogue, which is what Thomson 
advocates for, is important for generating understanding, it must not be seen as an end in itself but as a means to an end. Where gross injustices have been perpetrated, justice must not only be done, but it must be seen to have been done. So, for example, the imprisonment of the warlords Taylor and Gbagbo is just one small aspect of justice - the retributive aspect. Without addressing the aspects of restorative and redistributive justice, the very conditions that generated the wars in the first place, their attendant injustices will remain in place - providing the grounds for the attendant grievances to fester and bloom into new crises in the future. For peace to reign, therefore, in the spirit of Micah 6:8, it is imperative that besides punishing the offenders, restitution of some sort should accrue to the offended (restorative justice), and the inequities ensconced in the socio-economic and geopolitical fabric of the society have to be addressed (redistributive justice).

\section{Conclusion}

We began our study by exploring the biblical understanding of peace and justice, as a way of properly grounding the study. Peace, from a biblical standpoint, includes absence of conflict, being reconciled with one's Creator, living well and being well secured in one's self and environment. Justice has to do with the faithful administration of justice and the maintenance of right relationships between persons within a community.

I began the study of Micah 6:8 with a survey of the socialhistorical context of the prophet's times, which are shown to be prevalent with injustices of every kind: murders, corruption and bribery in the courts and in the bureaucracy, extortion and robberies, and all forms of gender-based violence were also pandemic. Micah showed Israel the path for overcoming all of these evils to be the path of justice. Micah also pointed Israel to the importance of covenant loyalty that manifests itself in unfailing love, kindness and mercy as shown by God, which his covenant people ought to reflect back, as the moon reflects the sun's rays, in their relationship with God and with one another. Love of God unfailingly eventuates into love of the neighbour - true love sacrificially seeks the good not the hurt of its object. To cap it all up, Micah calls for a personal walk (relationship) with God ('walk humbly with your God'): it is a call for discipleship.

With regard to our context, where this study is being conducted, I demonstrated the absence of peace throughout much of Africa. This is a reflection of the absence of inner peace, where people lack peace with themselves, which only comes from peace with their Creator. From this study, it can be seen that the social context of the Israel of Micah's day is very similar to the prevailing social conditions of much of contemporary Africa, hence the relevance of Micah's message to contemporary Africa. It is my firm belief that following Micah's call is an invitation for us as African Christians to live out the full meaning of our union with Christ, and the outworking of that union will ineluctably bring transformation to our lives, our communities, our nations and our continent as a whole. At the communal level, all aspects of justice (retributive, restorative and redistributive) need to be addressed as a way ensuring that enduring peace prevails.

\section{Acknowledgements}

The author is thankful to the Nigerian Association of Biblical Studies (NABIS), which offered him the opportunity to present this essay as a conference paper in 2015. The original article has been edited and improved upon.

\section{Competing interests}

The author declares that he has no financial or personal relationships that may have inappropriately influenced him in writing this article.

\section{Authors' contributions}

C.T.A.T. is the sole author of this work.

\section{Ethical considerations}

This article followed all ethical standards for research without direct contact with human or animal subjects.

\section{Funding information}

This work was supported by the University of South Africa.

\section{Data availability statement}

Data sharing is not applicable to this article as no new data were created or analysed in this study.

\section{Disclaimer}

The views and opinions expressed in this article are those of the author and do not necessarily reflect the official policy or position of any affiliated agency of the author.

\section{References}

Brueggemann, W., 2010, 'Walk humbly with your god', Journal for Preachers (Pentecost) 33(4), 14-19.

Ekanola, A.B., 2009, 'Realizing the value of peace', Peace Review 21(2), 222-229. https://doi.org/10.1080/10402650902877468

'Equal Rights', Song written by Rolando E. Mclean, Anthony Dehaney, and A. Brown, for the full song see, viewed 25 June 2015, from http://www.metrolyrics.com/ equal-rights-lyrics-peter-tosh.html.

Glueck, N., 1967, Hesed in the Bible, Hebrew Union College Press, Cincinnati, OH.

Holladay, W.L., 1996, A concise Hebrew and Aramaic Lexicon of the Old Testament, Eerdmans, Grand Rapids, Ml.

Keil, C.F., 2001, 'Micah', in C.F. Keil \& F. Delistzsch (eds.), Commentary on the Old Testament: Minor prophets, vol. 10 of 14 vols., pp. 283-348, Hendrickson Publisher, Peabody, MA.

Longman III (ed.), Tremper., 2013, Baker illustrated bible dictionary, Baker Books, Grand Rapids, MI.

McComiskey, T.E., 1985a, 'Amos: Introduction and commentary', in F.E. Gaebelein (ed.). The Bible expositor's Bible commentary, vol. 7 of 12 vols., pp. 267-331, Zondervan Publishing House, Grand Rapids, MI,

McComiskey, T.E., 1985b, 'Micah', in F.E. Gaebelein (ed.), The expositor's Bible commentary: Daniel and the minor prophets, vol. 7 of 12 vols., pp. 395-445, Zondervan, Grand Rapids, MI.

Mulongo, L.S., Patrick, K., Peter, I.O., Oseko, J.K., Chedotum, A. \& Kurgat, A., 2010, 'Natural resources for justice, peace, and reconciliation in Africa', AFER 51-52(4-1), 547-561.

Ryken, L., Wilhoit, J. \& Longman, T., 1998, Dictionary of Biblical imagery, IVP Academic, Downers Grove, IL. 
Thomson, H., 2009, 'Satisfying justice', International Journal of Public Theology 3(3), 319-338.

Tushima, C.T.A., 2011, The fate of Saul's progeny in the reign of David, Pickwick Publications, Eugene, OR.

Tushima, C.T.A., 2013, 'The meaning of God's 'Hesed' within mission as reconciliation', in R. Schreiter \& K. Jørgensen (eds.), Mission as ministry of reconciliation, pp. 90-100, Regnum, Oxford.
Tushima, C.T.A., 2016, 'The Yahwenomics of land and social justice and contemporary land resource crises in Nigeria', IOSR-Journal of Humanities and Social Sciences 21(9), 38-50. https://doi.org/10.9790/0837-2109123850

Waltke, B.K. \& O'Connor, M., 1990, Introduction to Biblical Hebrew Syntax, Eisenbrauns, Winona Lake, IN.

Youngblood, R.F., 1986, 'Peace', in G.W. Bromiley (ed.), International standard Bible encyclopedia, pp. 731-733, Eerdmans, Grand Rapids, MI. 